\title{
Comparative Study of LEED, BREEAM and GRIHA Rating System
}

\author{
${ }^{1}$ Laxman Jadhav, ${ }^{2}$ Shivani Lokhande, ${ }^{3}$ Apurva Bade ${ }^{4}$ Anant Tupe ${ }^{5}$ Arun Sankpal \\ ${ }^{1}$ Graduate Student, ${ }^{2}$ Graduate Student, ${ }^{3}$ Graduate Student, \\ ${ }^{4}$ Graduate Student, ${ }^{5}$ Assistant Professor \\ 1, 2, 3, 4, 5 Department of Civil Engineering, G. S. Moze Engineering College, \\ SPPU University, Pune, Maharashtra, India
}

\begin{abstract}
New Construction is developing at a rapid pace. It has led to the emergence of Green Building Rating System worldwide. Various rating system of the world has provided unique guidelines for each category of building viz. Retails, Schools, Core \& Shell, etc.

This paper aims to develop a systematic review of the development of green rating systems. The specific objectives are:

1)discover how interest and research in green rating systems have developed; 2) identify the similarity, difference, strength and weakness of green rating systems; 3 ) examine whether they fully assess the projects in all aspects of sustainability. Specifically, LEED (Leadership in Energy and Environmental Design), BREEAM (Building Research Establishment Assessment Method), GRIHA (Green Rating Integrated Habitat Assessment) were analyzed in this paper. The common aspect of all the rating system is to create a sustainable architecture in all respect so as to minimize negative environmental impact upon the environment. The three most prevailing rating system LEED, BREEAM and GRIHA has been studied and compared with Maximum Points and Mandatory Criteria.
\end{abstract}

Index Terms-Green Building, LEED, BREEAM, GRIHA, Rating System

\section{INTRODUCTION}

Buildings contribute towards major environmental impacts during their life cycle. Various resources such as soil, trees, water, and various formats of energy are used by the buildings. For instance Water, most vital resource, is consumed continuously during building construction as well as operation. Similarly several buildings along with usage of resources generate large amounts of waste, which can be recycled and can be reused. Thus, the challenge of a green building is to make optimum usage of resources and proper waste disposal at an affordable cost [4].

Recognizing the importance of sustainable building practices, "going green" and "environment sustainability" has been introduced for many years [8,9]. However, construction is still a major energy consumer based on official statistics [8]. This could be due to the passive attitude of construction practitioners towards adopting sustainable solutions [7]. Facing the rising energy costs and growing environmental concerns, the demand for sustainable building facilities with minimal environmental impact has been pushed recently [10,11]. Authorities and organizations initiated the rating systems for green buildings to minimize/optimize consumption of natural resources and control pollution. Buildings certified by those rating systems are considered as consuming less energy, providing a better living environment and contributing to the overall reputation of the property [12]. It is estimated that there are approximately 600 green rating systems globally [13]. BREEAM (Building Research Establishment Assessment Method) is known as the first rating tool to assess building performance based on certain target values for different criteria $[14,15]$. Based on the magnitude of green measures adopted, Points are Awarded to a building and, after appropriate weighting; a total score is ascribed to determine the rating of the building. This helps to convey the range of application of green measures in building construction. Worldwide various rating systems have been developed. The first environmental certification system was created in year 1996 the Building Research Establishment's Environmental Assessment Method (BREEAM) in UK. In year 1998 the Leadership in Energy and Environmental Design (LEED) green building rating system was introduced in US. In year 2007 the Green Rating Integrated Habitat Assessment (GRIHA) green building rating system was introduced in INDIA. Although green building rating certifications have been the focus of various researchers during the past 20 years, there is still no systematic review of the detailed criteria and the updated process of each rating system. A number of papers focused on the trend and credits in an individual rating tool, however, a comprehensive comparison of tools has not been established.

The focal comparison of this research is centered on LEED, BREEAM, and GRIHA. This study is a comprehensive assessment of every category and subcategory associated with each system. This research recommends unique green building rating system by comparing all above exiting rating system which covers each and every aspect required for the assessment and certification for green building. This unique rating system is comparatively less complex and provides the necessary perception about the project with ease. This research will focus largely on the way in which users are likely to interpret and implement the system, as opposed to focusing on requirements of system overall [6]. 


\section{GREEN BUILDING}

Green building is defined by the Office of the Federal Environmental Executive as "the practice of: (i) increasing the efficiency with which buildings and their sites use energy, water, and materials, and (ii) reducing building impacts of human health and the environment, through better siting, design, construction, operation, maintenance, and removal throughout the complete life cycle" [16].A green building is one whose construction and lifetime of operation assure the healthiest possible environment while representing the most efficient and least

Disruptive use of land, water, energy and resources.

The decision to build green should be made before the site is selected, as many of the green criteria are affected by site characteristics and some sites are inappropriate for certain green projects. One of the first steps in the green design process is to establish firm environmental goals for the project like energy efficiency, water conservation, onsite treatment of rain water and storm water, material and resources management, construction waste management, and to assign responsibility for meeting these goals to specific members of the design team. Each goal needs a champion who will see that objective through to the end.

The benefits of building green include cost saving from reduced energy, water and waste, lower operation and maintenance cost, and enhance occupant's productivity and health. However, it may include higher initial cost, but higher ROI and return on assets are key benefits [6].

\section{GREEN BUILDING RATING SYSTEM}

A green building rating system is an evaluation tool that measures environmental performance of a building through its life cycle. It usually comprises of a set of criteria covering various parameters related to design, construction and operation of a green building. Each criterion has preassigned points and sets performance benchmarks and goals that are largely quantifiable. Some of the successful international rating programmes are listed and explained below [4].

\section{LEED}

Leadership in Energy and Environmental Design (LEED) was developed in the US in 1998. This is the most widely used green Building rating system in the world. The rating system is based on several environmental and building related criterions based on which the buildings are rated. The Indian Green Building Council adapted LEED system and launched LEED India version on 1st January 2007.

There are more than 650 LEED certified green buildings in India such as CII-Godrej GBC, ITC Green Centre Gurugram, Wipro Gurugram etc.

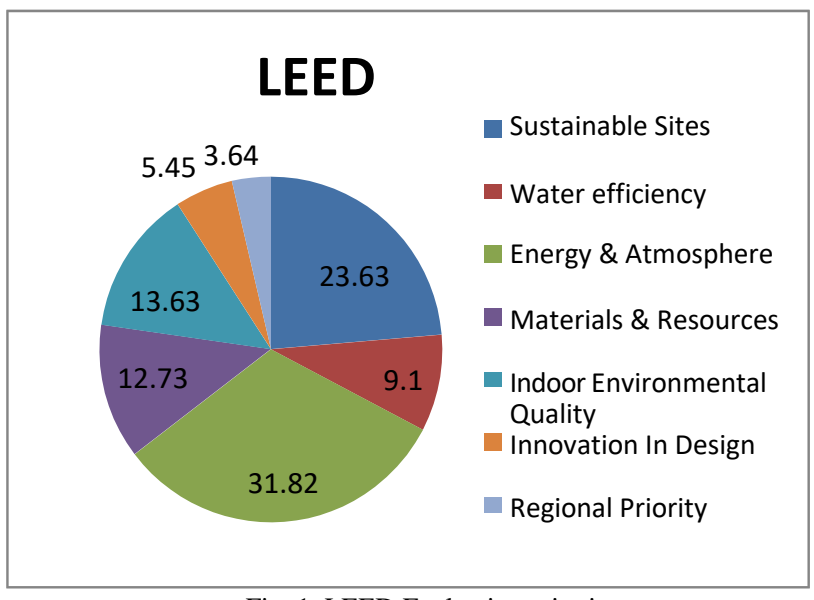

Fig. 1. LEED Evaluation criteria

- $\quad$ Credit Points under Different Categories

$>\quad 100$ possible points under the five core categories - SS, WE, EA, MR \& IEQ

$>\quad 6$ possible points under 'Innovation in Design'

$>\quad 4$ possible points under 'Regional Priority'

$>\quad$ Total possible points achieved are 110 .

- $\quad$ Credit Point for Different Levels of Certification

Table 1 - LEED Rating Pattern

\begin{tabular}{|l|l|}
\hline Rating & Points \\
\hline LEED Certified & $40-49$ \\
\hline LEED Silver Certified Level & $50-59$ \\
\hline LEED Gold Certified Level & $60-79$ \\
\hline LEED Platinum Certified Level & \multicolumn{2}{|c|}{$>80$} \\
\hline
\end{tabular}




\section{BREEAM}

Building Research Establishment's Environmental Assessment Method (BREEAM) was developed in the United Kingdom in 1990 and is one of the earliest building environmental assessment methods. BREEAM covers a range of building types including - offices, homes, industrial units, retail units, and schools. When a building is assessed, points are awarded for each criterion and the points are added for a total score. The overall building performance is awarded a 'Pass', 'Good', 'Very Good' or 'Excellent' rating based on the score. BREEAM has separate criteria/checklist for evaluation of Design and Procurement and for Management and Operation of buildings.

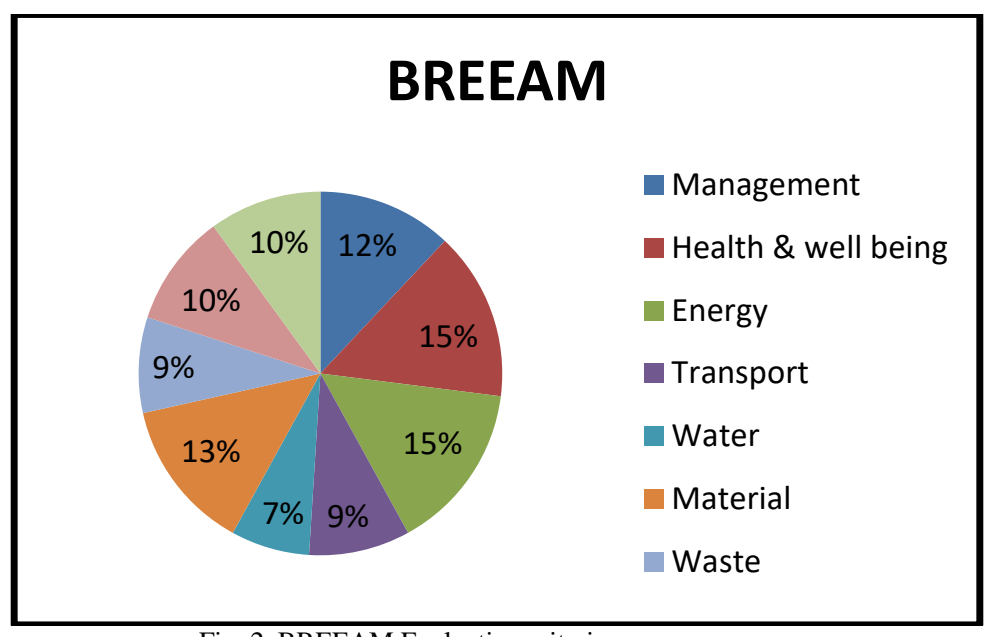

Fig. 2. BREEAM Evaluation criteria

* Credit Points under Different Categories

- 100 possible points under the five core categories - M, HW, E, T, W, M \& W

- An additional $1 \%$ can be added to the final score of the relevant category for each 'innovation credit' achieved (up to a maximum of $7 \%$ )

Table 2 - BREEAM Rating Pattern

\begin{tabular}{|l|l|}
\hline \multicolumn{1}{|c|}{ BREEAM Rating } & \% Score \\
\hline Outstanding & $\geq 85$ \\
\hline Excellent & $\geq 70$ \\
\hline Very Good & $\geq 55$ \\
\hline Good & $\geq 45$ \\
\hline Pass & $\geq 30$ \\
\hline Unclassified & $<30$ \\
\hline
\end{tabular}

\section{GRIHA}

Most of the internationally adopted rating systems have been framed to suit the building industry of that particular country. The Energy Resource Institute (TERI) New Delhi, with an objective of sustainable development, took the responsibility of developing a rating system to measure building's environmental performance in the context of India's varied climate and building practices and to encourage the construction of Green Buildings in India. The rating system will evaluate the performance of the building for its entire life cycle based on the Green Building techniques adopted during construction, operation and maintenance of the building. This rating system developed by TERI is called as Green Rating for Integrated
Habitat Assessment (GRIHA).

GRIHA is India's official Green Building rating program. It is a 5 star rating system purely based on the environmental performance of the building. GRIHA is formed by The Energy Resource Institute New Delhi (TERI) under the Ministry of New and Renewable Energy (MNRE). The process of rating is limited to new buildings only. May it be commercial, educational and residential or any building built to serve any purpose [4].

The certification is based on 34 criterions for which marks are awarded out of 100 for buildings with more than 2500 sq. meter. Built-up area. The rating pattern according to the marks scored by the building is as shown in the table. 


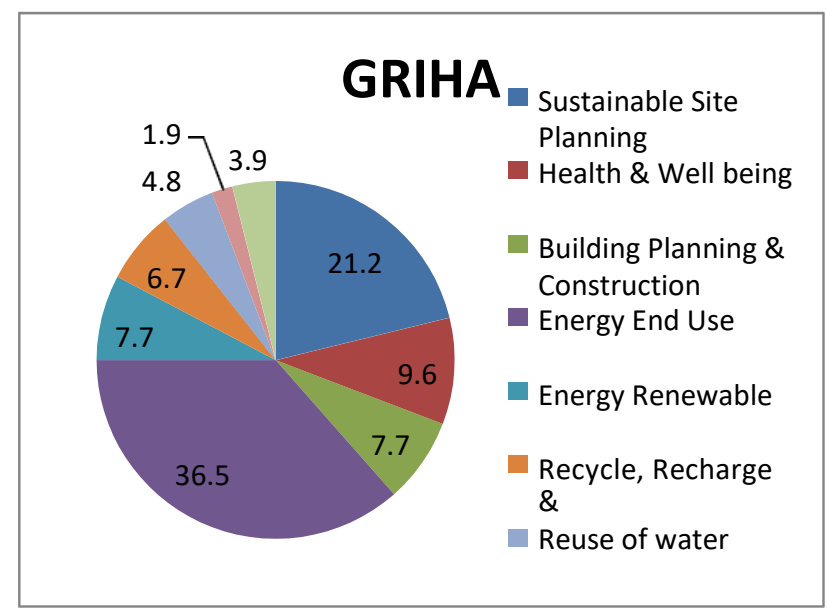

Fig. 3. GRIHA Evaluation criteria

\section{Credit Points under Different Categories}

100 possible points under the Eight categories

4 possible points under 'Innovation in Design'

Total possible points achieved are 104.

Table 3 - GRIHA Rating Pattern

\begin{tabular}{|l|l|}
\hline Rating & Points \\
\hline One star & $50-60$ \\
\hline Two star & $61-70$ \\
\hline Three star $71-80$ \\
\hline Four star & $81-90$ \\
\hline Five star & $>91$ \\
\hline
\end{tabular}

\section{COMPARISON OF BREEAM, LEED AND GRIHA}

\begin{tabular}{|c|c|c|c|c|}
\hline Sr. no. & $\begin{array}{l}\text { CATEGORY } \\
\end{array}$ & BREEAM & LEED & GRIHA \\
\hline 1 & $\begin{array}{lcccc}\begin{array}{l}\text { MANAGEMENT/ } \\
\text { PROJECT MGMT/ SITE ASPECT }\end{array} & \text { SITE/ } & \text { SITE } & \& \\
\end{array}$ & & & \\
\hline $\mathrm{a}$ & $\begin{array}{l}\text { Site selection/ Brownfield redevelopment/ Reuse of land/ } \\
\text { Reclaimed land/ contaminated land/ sustainable construction }\end{array}$ & $\checkmark$ & $\checkmark$ & $\checkmark$ \\
\hline b & $\begin{array}{l}\text { Erosion \& Sedimentation control/ Topsoil \& Fill Removal from } \\
\text { site }\end{array}$ & $\mathrm{X}$ & $\checkmark$ & $\checkmark$ \\
\hline c & $\begin{array}{l}\text { Urban redevelopment/ Reduced site disturbance/ Ecological } \\
\text { value of site \& protection of ecological features/ Mitigating } \\
\text { ecological impact/ Enhancing site ecology/ Ecological value of } \\
\text { site/ Greenery provision/ construction site impact/ Long term } \\
\text { impact on biodiversity }\end{array}$ & $\checkmark$ & $\checkmark$ & $\checkmark$ \\
\hline d & $\begin{array}{l}\text { Hard Landscaping \& Boundary protection/ Environmental } \\
\text { mgmt./ Environmental mgmt. practices/ Landscaping \& Planters/ } \\
\text { Microclimatic around building/ Health, Safety \& Environmental } \\
\text { mgmt./ Environmental purchasing practices }\end{array}$ & $\checkmark$ & $\mathrm{X}$ & $\checkmark$ \\
\hline $\mathrm{e}$ & $\begin{array}{l}\text { Responsible Construction practices/ Maintainability/ } \\
\text { Commissioning clauses/ Commissioning building Tuning/ } \\
\text { Environmental mgmt. Practices (CONQUAS)/ Building \& Site } \\
\text { Operation \&Maintenance }\end{array}$ & $\checkmark$ & $\mathrm{x}$ & $\checkmark$ \\
\hline 2 & ENERGY/ ENERGY EFFICIENCY/ ENERGY USE & & & \\
\hline $\mathrm{a}$ & $\begin{array}{l}\text { Fundamental building system commissioning/ Measurement \& } \\
\text { verification/ Energy monitoring/ Energy conditional } \\
\text { requirement/ Electrical sub- metering/ Testing \& commissioning } \\
\text { / Metering \& monitoring }\end{array}$ & $\checkmark$ & $\checkmark$ & $\checkmark$ \\
\hline $\mathrm{b}$ & $\begin{array}{l}\text { Minimum energy performance/ Optimize energy performance/ } \\
\text { Energy efficient cold storage/ Energy eff. Lab system/ Energy } \\
\text { eff. Transportation system/ Energy eff. Equipment/ Peak energy } \\
\text { demand Reduction/ Eff. External lighting/ Lighting zoning \& } \\
\text { control/ Centralized energy system/ Thermal performance of } \\
\text { building envelope/ Natural ventilated design \& A/c system/ } \\
\text { Energy eff. Features/ Annual energy use in building/Ventilation } \\
\text { system in mechanically ventilated building/ Lighting system in } \\
\text { mechanically ventilated building/ Energy eff. Lighting in public } \\
\text { areas/ Energy eff. applications/ Energy mgmt./ A/c units }\end{array}$ & $\checkmark$ & $\checkmark$ & $\mathrm{x}$ \\
\hline
\end{tabular}




\begin{tabular}{|c|c|c|c|c|}
\hline $\mathrm{c}$ & $\begin{array}{l}\text { Renewable energy/ Green power/ } \\
\text { Energy improvement/ renewable energy system }\end{array}$ & $\mathrm{X}$ & $\checkmark$ & $\checkmark$ \\
\hline 3 & WATER EFFICIENCY & & & \\
\hline a & $\begin{array}{l}\text { Water consumption/ Water monitoring/ Water meter/ Water } \\
\text { usage monitoring/ Monitoring \& Control }\end{array}$ & $\checkmark$ & $\checkmark$ & $\checkmark$ \\
\hline $\mathrm{b}$ & $\begin{array}{l}\text { Water use reduction/ Water eff. Landscaping/ Water leak } \\
\text { detection \& prevention/ Water eff. Equipment/ Occupant } \\
\text { amenity potable water efficiency/ Landscaping irrigation water } \\
\text { eff./ Heat rejection water consumption/ Fire system water } \\
\text { consumption/ Potable water use in lab/ Water eff. fitting/ } \\
\text { Irrigation system \& landscaping/ Water consumption of cooling } \\
\text { tower/ Annual water use/ Water eff. Irrigation }\end{array}$ & $\checkmark$ & $\checkmark$ & $\checkmark$ \\
\hline $\mathrm{c}$ & $\begin{array}{l}\text { Innovative waste water technologies/ Storm water mgmt./ Water } \\
\text { recycling effluent discharge to foul sewers }\end{array}$ & $\mathrm{X}$ & $\checkmark$ & $\checkmark$ \\
\hline 4 & MATERIALS & & & \\
\hline $\mathrm{a}$ & $\begin{array}{l}\text { Building reuse/ Reuse of Façade/ Reuse of structure/ Building } \\
\text { Reuse }\end{array}$ & $\mathrm{X}$ & $\checkmark$ & $\mathrm{X}$ \\
\hline b & $\begin{array}{l}\text { Storage \& collection of recyclables/ construction water mgmt./ } \\
\text { Resource reuse/ Recycled content/ Construction waste mgmt./ } \\
\text { Recycled aggregates/ Recycled content of concrete/ Recycled } \\
\text { content of steel/ Recycled content and Reused products \& } \\
\text { materials/ Sustainable timber flooring/Loose } \\
\text { furniture/ Deconstruction/ Rapidly renewable materials/ Life } \\
\text { cycle impacts/ Sustainable procurement/ Recycling waste } \\
\text { storage/ Sustainable construction/ Sustainable } \\
\text { Products/ Adaptability \& Deconstruction/ Sustainable forest } \\
\text { products/ Waste Recycling facilities/ Waste mgmt. }\end{array}$ & $\checkmark$ & $\checkmark$ & $\checkmark$ \\
\hline $\mathrm{c}$ & Local or Regional Materials & $\mathrm{X}$ & $\checkmark$ & $\mathrm{X}$ \\
\hline 5 & $\begin{array}{l}\text { INDOOR ENVIRONMENTAL QUALITY/ HEALTH AND } \\
\text { WELL BEING }\end{array}$ & & & \\
\hline
\end{tabular}

\begin{tabular}{|c|c|c|c|c|}
\hline a & $\begin{array}{l}\text { Minimum IAQ performance/ Construction IAQ mgmt. plan / Air } \\
\text { change effectiveness/ IAQ in wet areas/ Construction IAQ } \\
\text { mgmt./ IAQ in car parking/ IAQ in public transport interchanges }\end{array}$ & $\checkmark$ & $\checkmark$ & $\checkmark$ \\
\hline $\mathrm{b}$ & $\begin{array}{l}\text { Environment tobacco smokes (ETS) control/ CO2 monitoring/ } \\
\text { Low-emitting material/ Indoor chemical \& pollutant source } \\
\text { control/ CO2 \& VOC monitoring \& control/ Hazardous } \\
\text { materials/ Volatile Organic Compounds/ Formaldehyde } \\
\text { minimization/ Mould prevention/ Indoor air } \\
\text { pollutants/Biological contaminations/ Integrated pest mgmt./ } \\
\text { Indoor source of air pollution }\end{array}$ & $\mathrm{X}$ & $\checkmark$ & $\checkmark$ \\
\hline $\mathrm{C}$ & $\begin{array}{l}\text { Reduced heat island effect/ Thermal comfort/ Thermal } \\
\text { Insulation/ Thermal performance of building envelope- RETV/ } \\
\text { Thermal comfort in centrally A/c premises/ Thermal comfort in } \\
\text { A/c or Naturally ventilated premises }\end{array}$ & $\checkmark$ & $\checkmark$ & $\mathrm{X}$ \\
\hline $\mathrm{d}$ & $\begin{array}{l}\text { Ventilation efficiency/ Ventilation rates/ Naturally ventilated } \\
\text { design \& } \mathrm{A} / \mathrm{c} \text { system/ Ventilation in } \mathrm{A} / \mathrm{c} \text { premises/ Localized } \\
\text { ventilation/ Ventilation in common areas }\end{array}$ & $\mathrm{X}$ & $\checkmark$ & $\checkmark$ \\
\hline $\mathrm{e}$ & $\begin{array}{l}\text { Day lighting \& views/ Visual comfort/ Day lighting/ Day light } \\
\text { glare control/ High frequency ballasts/ Electric lighting levels/ } \\
\text { External views/ Artificial lighting/ Natural lighting/ Interior } \\
\text { lighting in normally occupied areas/ Interior lighting in not } \\
\text { occupied areas }\end{array}$ & $\checkmark$ & $\checkmark$ & $\checkmark$ \\
\hline $\mathrm{F}$ & Safety and Security/ Fire Safety/ Security & $\checkmark$ & $\mathrm{X}$ & $\mathrm{X}$ \\
\hline $\mathrm{g}$ & $\begin{array}{l}\text { Acoustic Performance/ Internal noise Level/ Noise Level/ Room } \\
\text { Acoustics/ Noise Isolation/ Background Noise }\end{array}$ & $\checkmark$ & $\mathrm{X}$ & $\checkmark$ \\
\hline 6 & TRANSPORTATION & & & \\
\hline a & $\begin{array}{l}\text { Alternative transportation/ Public transport accessibility/ } \\
\text { Commuting mass transport/ Green transport/ Local transport/ } \\
\text { Vehicular access }\end{array}$ & $\checkmark$ & $\checkmark$ & $\checkmark$ \\
\hline $\mathrm{b}$ & Alternative transportation/ Cyclist facilities/ Green transport & $\checkmark$ & $\checkmark$ & $\mathrm{X}$ \\
\hline $\mathrm{c}$ & $\begin{array}{l}\text { Alternative transportation/ Travel plan/ Fuel eff. Transport/ } \\
\text { Green transport }\end{array}$ & $\checkmark$ & $\checkmark$ & $\mathrm{X}$ \\
\hline
\end{tabular}




\begin{tabular}{|l|l|l|l|l|}
\hline $\mathrm{d}$ & $\begin{array}{l}\text { Alternative transportation/ Maximum car parking capacity/ Car } \\
\text { park minimization }\end{array}$ & $\checkmark$ & $\checkmark$ \\
\hline $\mathrm{e}$ & Pedestrian route/ Green transport/Local transport & X & X & $\checkmark$ \\
\hline $\mathrm{f}$ & $\begin{array}{l}\text { Proximity to amenities/ Neighborhood amenities/ Amenities } \\
\text { features }\end{array}$ & $\checkmark$ & $\mathrm{X}$ \\
\hline $\mathbf{P}$ & PLLUTION & & $\checkmark$ & \\
\hline $\mathrm{a}$ & $\begin{array}{l}\text { Light pollution reduction/ Reduction of night K=Light pollution/ } \\
\text { Light pollution }\end{array}$ & $\checkmark$ & \\
\hline $\mathrm{b}$ & $\begin{array}{l}\text { Ozone protection/ Ozone depletion potential/ Ozone depletion } \\
\text { substances/ Impact of refrigerants/ Refrigerant GWP/ } \\
\text { Refrigerant leak detection \& recovery/ CFC reduction in HVAC } \\
\text { \& R equipment/ Reduction in CO2 emission/ Low \& Zero } \\
\text { carbon technology. }\end{array}$ & $\checkmark$ & $\checkmark$ \\
\hline $\mathrm{c}$ & No emissions & $\checkmark$ & $\checkmark$ \\
\hline
\end{tabular}

\section{$=$ CONSIDERED}

\section{CONCLUSIONS}

$\mathrm{X}=$ NOT CONSIDERED
Green building is a building which is environment friendly as it is using certain principles during its design, construction and functioning phase which allow it to get maximum advantages from the environment and cause minimum damage. There are many factors which have to be considered while constructing a green building. It is very necessary to know how effective a particular project is in term of its environment friendliness. The unique system suggested would rate the building on various factors so as to give a fair idea of where it stands in being a green building.

All the buildings which are being built newly should focus on adopting green building techniques in its possible way. Use of renewable sources, recycling wastes and water, cost effective building techniques should be adopted etc. willingly by the builders and developers while constructing a structure.

The existing Green Building Rating systems should also rate already constructed old buildings. If not, a new rating pattern for rating of old buildings should be developed. A new rating system for small scale projects considering the views and needs of the small cities should be designed keeping in mind the local scenario. By doing this the interest of the people as well as developer community towards adopting green building techniques may see a hike.

\section{REFERENCES}

[1] Dat Tien Doan, Ali Ghaffarianhoseini, Nicola Naismith , Tongrui Zhang, Amirhosein Ghaffarianhoseini , John Tookey "A critical comparison of green building rating systems"

[2] Iliyas ikbal sande, Prof. N S. Phadtare (2015) "Comparative study of LEED and GRIHA rating system" VOL, 3

[3] Rohan V. Nalawade, Dr. S.G. Sonar "Comparative Review criteria utilization by LEED and GRIHA: Green building Rating systems for New construction in India"

[4] Nadeem A. Sanadi ,Samreen S. Makandar "Limitations of Green Building Rating Systems - A case of LEED and GRIHA" (2019),VOL .06
[5] Himanshu Agarwal, Hari Kumar Singh, Sanjay Vashishtha "Comparison between three most prevailing green building rating systems of India" (2017),VOL. 05

[6] Dr.M.N. Hedaoo, Mr. Sharad Khese "A Comparative Analysis Of Rating Systems in Green Building" (2016),VOL.3

[7] J.K.-W. Wong, K.-L. Kuan, Implementing 'BEAM Plus' for BIM-based sus-tainability analysis, Automation Constr. 44 (2014) $163 \mathrm{e} 175$.

[8] J.K.W. Wong, J. Zhou, Enhancing environmental sustainability over building life cycles through green BIM: a review, Automation Constr. 57 (2015) 156e165

[9] J.A. Lorenzen, Going Green: the process of lifestyle change 1, in: Sociological Forum, Wiley Online Library, 2012, pp. $94 \mathrm{e} 116$

[10] S. Azhar, W.A. Carlton, D. Olsen, I. Ahmad, Building Information Modeling for sustainable design and LEED® rating analysis, Automation Constr. 20 (2011) 217e224.

[11] F. Jalaei, A. Jrade, Integrating Building Information Modeling (BIM) and LEED system at the conceptual design stage of sustainable buildings, Sustain. Cities Soc. 18 (2015) 95e 107.

[12] F. Jalaei, A. Jrade, Integrating Building Information Modeling (BIM) and LEED system at the conceptual design stage of sustainable buildings, Sustain. Cities Soc. 18 (2015) 95e 107.

[13] W. Lee, A comprehensive review of metrics of building environmental assessment schemes, Energy Build. 62 (2013) $403 \mathrm{e} 413$.

[14] L.M. Mitchell, Green Star and NABERS: learning from the Australian expe rience with green building rating tools, Energy Effic. (2010) 93.

[15] D.E. Shiers, "Green" developments: environmentally responsible buildings in the UK commercial property sector, Prop. Manag. 18 (2000) 352e365.

[16] Robert Cassidy. Office of the Federal Environmental Executive, "The Federal Commitment to Green Building: Experiences and Expectations," 18 September 2003. 